\title{
KEBERADAAN SARANA DAN PRASARANA TRANSPORTASI DALAM INDUSTRI PARIWISATA DI KEPULAUAN ANAMBAS
}

\section{EXISTANCE OF TRANSPORTATION FACILITIES AND INFRASTRUCTURES IN TOURISM INDUSTRY IN ANAMBAS}

\author{
Sjafril Karana dan Andi Cahyo \\ Direktorat Pengkajian Teknologi Rekayasa Industri Maritim \\ Gedung Teknologi 2, Lt3, PUSPIPTEK, Serpong \\ Email : andi.cahyo@bppt.go.id, sjafril.karana@bppt.go.id
}

\begin{abstract}
Abstrak
Terdapat banyak obyek wisata di Kabupaten Kepulauan Anambas yaitu berupa wisata pantai, wisata alam, wisata bawah laut, wisata sejarah, serta wisata budaya dan edukasi, namun pemanfaatannya belum optimal. Kendala utama yang dihadapi adalah kondisi sarana dan prasarana yang masih terbatas baik untuk menuju objek wisata maupun dilokasi objek wisata, serta rendahnya kapasitas sumberdaya masyarakat dalam kegiatan kepariwisataan. Bila sektor pariwisata ini berkembang tentunya akan mendorong pertumbuhan ekonomi daerah secara menyeluruh, oleh sebab itu potensi wisata daerah ini perlu dimanfaatkan secara maksimal, sehingga menjadi salah satu tulang punggung pengembangan perekonomian wilayah Kepulauan Anambas. Sementara ini salah satu faktor penunjang aktifitas kepariwisataan yang perlu dkiembangkan adalah sarana transportai laut untuk angkutan wisata yang memang belum tersedia. Penelitian ini diawali dengan identifikasi permasalahan melalui data sekunder dilanjutkan dengan observasi lapangan kemudian dievaluasi. Dari hasil analisis dapat disimpulkan bahwa untuk sarana yang cocok dikembangkan adalah kapal cepat jenis Catamaran, sedangkan untuk prasarana angkutan darat perlu ditingkatkan terutama yang menuju objek-obje wisata. Disamping itu simpulsimpul transportasi di pelabuhan-pelautama perlu pula dikembangkan, termasuk pusat-pusat informasi kepariwisataan serta keterlibatan masyarakat lokal secara aktif.
\end{abstract}

Kata kunci : sarana, prasarana transportasi, industri pariwisata, Anambas

\begin{abstract}
There are many tourist destinations in Anambas Island including seaside tour, panorama, under water, historial places, cultural and educational tours. However, the utilization of those tourism objects are not yet optimized. The main existing barriers is due to the limited facilities and infrastructures availability such as transportation facilities for transporting tourist either to the location of tourism object or within the area of tourism object as well as the involvement of low skilled human resources in tourism activities. Shortly after improving this tourism sector, it will of course speed up the economy growth as a whole. Therefore, this local potential tourism needs to beutilized optimally in order to be one of the backbone of the regional economy development in Anambas island. At the moment, one among other supporting factors for tourism activities specially for sea transportation means should be developed since the suitable sea transportation has not yet been available. This study has been begun with the identification of problems through secondary data and followed by observation on the field and evaluation. From the analysis, it can be concluded that the most suitable sea transportation means is the high speed catamaran vessel. Meanwhile, the land transportation sector for tourism objects purposes also needs to be enhanced. Besides, the transportation center, information center for tourism purposes, as
\end{abstract}


well as the involvement of the local communities actively also need to be developed.

\section{Keywords: facilities, transport infrastructure, tourism industry, Anambas}

Diterima (received) : 20 Mei 2016, Direvisi (reviewed) : 20 Juni 2016, Disetujui

(accepted) : 15 Juli 2015

\section{PENDAHULUAN}

Keberadaan industri kepariwisataan di dunia dewasa ini merupakan salah satu industri yang sangat berkembang, demikian hal di Indonesia yang merupakan negara agraris yang memiliki berbagai obyek wisata, sektor pariwisata ini diharapkan dapat meningkatkan pertumbuhan ekonomi, namun kenyataannya baru sebagian kecil yang sudah dimanfaatkan, salah satunya adalah Pulau Bali yang saat ini menjadi icon pariwisata Indonesia.

Banyak sekali objek wisata alam yang belum dikembangkan tersebar di seluruh Indonesia sehingga tidak dikenal oleh para wisatawan baik domestik maupun manca negara, objek-objek wisata tersebut memiliki potensi alam yang luar biasa menarik jika dikembangkan secara optimal, salah satunya adalah yang terdapat di Kabupaten Anambas. Walaupun secara fisik daerah ini memiliki kekayaan alam yang luar biasa, namun pemanfaatan dan pengelolaannya belum serius dan maksimal (Jambak Zam,2014) ${ }^{(1)}$.

Pemanfatan potensi alam ini tentunya akan dapat meningkatkan pendapatan daerah, disamping itu juga mampu menumbuh dan memperluas kesempatan kerja ke sektorsektor lainnya, seperti industri kerajinan rakyat, agrowisata, pelayanan jasa perhubungan, perdagangan, dan pengembangan budaya.

Berbagai kendala telah menyebabkan tidak berkembangnya aktifitas industri pariwisata di daerah ini, terutama masalah keberadaan sarana baik untuk menuju Kabupaten Anambas dan lokasi objek wisata maupun minimnya sarana dan prasarana penunjang di lokasi objek wisata. Untuk transportasi lokal misalnya, sementara ini terbatas hanya untuk berbagai keperluan masyarakat yaitu berupa perahu/kapal motor dan kapal cepat dengan peralatan keselamatan seadanya, sedangkan untuk transportasi darat didominasi oleh sepeda motor.

Dibanding dengan luas perairannya, keberadaan sarana transportasi laut khususnya masih sangat kurang apalagi khusus untuk aktifitas kepariwisataan, hal ini tentu saja menjadi salah satu faktor penghambat dalam rangka mendorong terciptanya pusat-pusat pertumbuhan industri pariwisata.

Mengingat daerah ini merupakan daerah kepulauan, maka untuk meningkatkan aktifitas kepariwisataan perlu ditunjang dengan keberadaan sarana transportasi yang memadai baik jumlah maupun kualitasnya. Demikian pula prasarana/jalan darat juga perlu dikembangkan karena saat ini terlihat kondisinya sangat memprihatinkan terutama untuk menuju berbagai obyek wisata. Berkembangnya industri pariwisata di daerah ini diharapkan dapat pula menunjang upaya meningkatkan target capaian wisatawan 20 juta pada tahun 2019.

\section{TINJAUAN PUSTAKA \\ Industri Pariwisata}

Menurut Damanik dan Weber $(2006)^{(2)}$, pariwisata adalah fenomena pergerakan manusia, barang dan jasa yang sangat komplek, terkait erat dengan organisasi, hubungan kelembagaan dan individu, penyedia kebutuhan layanan dan sebagainya. Sedangkan Roni Khairon mengutip teori Glasson (1990) $)^{(3)}$, industri pariwisata merupakan kegiatan yang dapat memacu timbulnya kegiatan lain (multiplier effects), dapat menggerakkan industri-industri lain sebagai pendukungnya. Komponen utama industri pariwisata adalah daya tarik wisata berupa destinasi dan atraksi wisata, perhotelan, restoran dan transportasi local, sementara komponen pendukungnya, mencakup industri-industri dalam bidang transportasi, makanan dan minuman, perbankan.

Selanjutnya Roni Khaironi (2008) $)^{(3)}$, mengatakan setelah wisatawan datang pada suatu negara/destinasi wisata, mereka pasti akan membelanjakan uang untuk memenuhi kebutuhan dan keinginannya selama mereka tinggal di negara atau destinasi tersebut. Uang yang dibelanjakan wisatawan itu tidak pernah berhenti beredar, akan tetapi berpindah dari satu tangan ke tangan orang lain atau dari satu perusahaan ke perusahaan lain, hal ini tentunya dapat mamacu pertumbuhan perekonomian masyarakat yang ikut memanfaatkannya. Penelitian yang dilakukan Gretzel, et al., 2004 ${ }^{(4)}$ di Illionis Amerika menyatakan bahwa pelayanan personal 
pariwisata merupakan salah satu kunci untuk meningkatkan volume jumlah wisatawan ke suatu daerah.

Pelayanan yang dimaksud oleh Gretzel, antara lain menyediakan suatu katalog tentang nuansa alam atau budaya di daerah setempat, menyediakan berbagai informasi seperti hiburan yang bersifat in door, atraksi, tempat tinggal keluarga, sarana pendukung di tempat tinggal, pusat-pusat perbelanjaan, sejarahsejarah yang berkaitan dengan daerah setempat, sarana dan prasarana transportasi, dan adanya penyediaan alat-alat permainan.

Penelitian Bursan (2006) ${ }^{(5)}$ menghasilkan bahwa obyek wisata dan sarana prasarana wisata berpengaruh terhadap kepuasan wisatawan. Penelitian yang dilakukan oleh Sudiarta $(2005)^{(6)}$ di Desa Sarangan Bali menyatakan bahwa akses transportasi dapat meningkatkan perkembangan wisata serta jumlah wisatawan karena akses menuju obyek wisata menjadi semakin lancar dan biaya yang ditimbulkan semakin murah. Dampak positif ini berpengaruh juga terhadap ekonomi masyarakat dengan munculnya wiraswasta baru berupa cafe-cafe dan penangkaran hewan ternak penyu.

Penelitian Braun didukung oleh Sigala \& Sakellaridis $(2004)^{(7)}$ menyatakan bahwa teknologi informasi internet berupa website memberikan kontribusi terhadap peningkatan paiwisata daerah. Website yang digunakan untuk memasarkan produk yang ada pada suatu daerah. Dalam kaitannya dengan kepariwisataan, transportasi merupakan alat yang sangat penting agar para wisatawan dapat menikmati mayoritas tempat wisata berupa hiburan dan wisata berupa atraksi di daerah setempat, karena dengan alat transportasi yang sudah diakomodasi oleh pemerintah daerah setempat para wisatawan dapat berpindah dari satu obyek wisata ke obyek yang lainnya dalam waktu yang relatif pendek. Yoeti A., (2009) ${ }^{(8)}$ mengatakan bahwa ndustri pariwisata merupakan kumpulan dari bermacaam-macam usaha yang secara bersama-sama menghasilkan barang dan jasa-jasa (goods and servises) yang dibutuhkan wisatawan pada khususnya dan traveller pada umumnya selama dalam perjalanannya.

Aspek-aspek yang tercakup dalam industri pariwisata menurut Kusmayadi dan Endar Sugiarto, (2000) ${ }^{(9)}$ antara lain meliputi restoran ; penginapan ; pelayanan perjalanan ; transportasi ; pengembangan daerah tujuan wisata ; fasilitas rekreasi; dan atraksi wisata. Menurut Ugy Soebiyantoro (2009) ${ }^{(10)}$, ketersediaan sarana transportasi akan memberikan kepuasan tersendiri bagi para wisatawan untuk mengunjungi obyek wisata di
Kabupaten Kebumen, karena berdampak kepada empat item indicator berikut yaitu : biaya yang dikeluarkan untuk menggunakan sarana transportasi lebih murah, akses yang mudah untuk mendapatkan sarana transportasi, penggunaan sarana transportasi yang tepat waktu dan kualitas layanan personil transportasi. Oleh sebab itu menurut Alaydrus Hadijah, (2016) $)^{(11)}$ transportasi umum yang terjadwal di kawasan wisata mutlak disediakan dalam upaya meningkatkan target pelancong 20 juta pada 2019.

\section{Kebijakan Kepariwisataan Nasional}

Menurut Undang Undang No. 10/2009(12), pembangunan kepariwisataan diarahkan untuk meningkatan pariwisata menjadi sektor andalan yang mampu menggalakkan kegiatan ekonomi termasuk kegiatan sektor lain yang terkait. Hal ini dimaksudkan agar pengembangan berbagai potensi kepariwisataan nasional dapat meningkatkan peluang kerja, pendapatan negara dan penerimaan devisa. Dan menurut Peraturan Pemerintah Nomor 50 Tahun 2011 ${ }^{(13)}$, pembangunan kepariwisataan nasional meliputi penyediaan dan pengembangan sarana, prasarana dan sistem transportasi angkutan jalan, sungai, danau dan penyeberangan, angkutan laut, angkutan udara, dan angkutan kereta api. Sedangkan strategi untuk mengembangkan dan meningkatkan kemudahan akses dan pergerakan wisatawan menuju destinasi dan pergerakan wisatawan di destinasi pariwisata nasional (DPN), adalah sebagai berikut :

a. Meningkatkan ketersediaan moda transportasi sebagai sarana pergerakan wisatawan menuju destinasi dan pergerakan wisatawan di destinasi pariwisata (DP) sesuai kebutuhan dan perkembangan pasar;

b. Mengembangkan keragaman jenis moda transportasi menuju destinasi dan pergerakan wisatawan di DP sesuai kebutuhan dan perkembangan pasar.

c. Ketersediaan prasarana simpul pergerakan moda transportasi pada lokasi-lokasi strategis di DPN sesuai kebutuhan dan perkembangan pasar; dan

d. Keterpaduan jaringan infrastruktur transportasi antara pintu gerbang wisata dan DPN serta komponen yang ada di dalamnya yang mendukung kemudahan transfer intermoda.

h. Pengembangan prasarana umum, fasilitas umum, dan fasilitas pariwisata dalam mendukung perintisan pengembangan DPN. 


\section{METODOLOGI}

Penelitian diawali dengan pengumpulan data sekunder melalui studi pustaka terutama tentang faktor-faktor yang mempengaruhi dan meningkatkan pengembangan industri pariwisata, sedangkan data primer diambil dari hasil kunjungan lapangan yang pernah dilakukan ke Kepulauan Anambas. Data yang diperoleh diantaranya meliputi kondisi iklim \& cuaca diperairan laut Kepulauan Anambas, perkembangan dan kondisi obyek -obyek wisata, kondisi sarana dan prasarana transportasi ketempat-tempat obyek wisata, prasarana penunjang dilokasi obyek wisata, perkembangan arus penumpang dari dan ke Anambas, pertumbuhan tempat penginapan/hotel, restaurant dan bank. Sedangkan obyek wisata yang dikunjungi diantarnya Air Terjun Temurun dan Vihara Gunung Dewa di Kecamatan Siantan dengan menggunakan kendaraan roda dua, Pulau Durai menggunakan kapal, dan Pantai Kesik menggunakan kendaraan roda dua. Sedangkan untuk kondisi prasarana seperti pelabuhan, yang dikunjungi diantaranya Pelabuhan Tarempa (Kecamatan Siantan), Pelabuhan Letung dan Pelabuhan Kuala Maras ( Kecamatan Jemaja).

Berdasarkan data dan informasi yang diperoleh baik sekunder maupun primer, dapat diketahui design constrain dalam pengembangan sarana transportasi laut, sehingga sarana transportasi laut yang cocok dikembangkan di daerah perairan Anambas adalah kapal cepat jenis Catamaran. Melalui metode parametric ratio design approach dengan menggunakan bantuan alat statistic $p$ chart, dapat ditentukan ukuran utama (principle dimention), berdasarkan ukuran utama tersebut dapat dibuat gambar recana umumnya menggunakan software Auto Cad.

Desain awal (preliminary design) kapal cepat Catamaran ini nantinya dapat dimanfaatkan sebagai masukan untuk tahap selanjutnya yaitu tahap pembuatan detail design yang tentunya didahului oleh contract design, sehingga diharapkan kapal yang dibuat nanti cocok untuk dioperasikan sebagai kapal wisata di perairan kepulauan Anambas.

\section{HASIL DAN PEMBAHASAN \\ Gambaran Umum}

Kabupaten Kepulauan Anambas memiliki sebagian besar wilayahnya terdiri dari lautan dan pulau-pulau yang tersebar di perairan Laut Natuna dan Laut Cina Selatan. Kabupaten ini terdiri dari 255 pulau dengan luas daratan 46.664,14 Km2 (1,38\%) dikelilingi oleh lautan seluas $46.033,81 \mathrm{Km}^{2}(98,62 \%)$, pulau yang sudah berpenghuni sekitar 26 pulau. Secara administratif daerah ini terbagi dalam tujuh kecamatan, dua kelurahan, dan 34 desa termasuk di dalamnya dua desa persiapan. Kondisi iklim dan cuaca di Kepulauan Anambas sangat dipengaruhi oleh perubahan arah angin, musim kemarau biasanya terjadi pada bulan Maret hingga Mei.

Kondisi perairannya tidak selalu tenang tetapi hanya berlangsung sekitar 4 bulan yaitu April s/d Agustus, selebihnya fluktuasi ketinggian gelombangnya cukup tinggi yaitu rata-rata berkisar 2,2 meter. Untuk perairan dalam tinggi ombak bisa mencapai $>3 \mathrm{~m}$, hal ini disebabkan perairan Anambas relatif terbuka, langsung berhadapan dengan laut bebas yaitu Laut Natuna sebelah selatan dan Laut Cina Selatan di sebelah utara, untuk wilayah perairan teluk dan selat kondisi perairannya relatif tenang dengan tinggi gelombang $<0,5 \mathrm{~m}$, hal ini disebabkan gelombang tersebut telah mengalami refraksi maupun difraksi.

Musim hujan terjadi pada bulan September hingga Februari, ketika angin bertiup dari arah Timur dan Selatan, curah hujan rata-rata dalam satu tahun berkisar $\pm 14.5 \mathrm{~mm} / \mathrm{jam}$ dengan kelembaban udara sekitar $47.25 \%$ dan temperatur berkisar $30^{\circ} \mathrm{C}$. Selain itu kedalaman laut di daerah-daerah pantai umumnya relative dangkal yaitu $<1,5 \mathrm{~m}$ dan banyak terdapat terumbu karang.

\section{Peran Sektor Pariwisata}

Distribusi prosentase produk domestic regional brutto menggambarkan strukturisasi pada suatu daerah, dengan melihat distribusi tersebut dapat diketahui sektor-sektor mana yang menjadi pondasi ekonomi utama dan sector-sektor mana yang memerlukan optimalisasi lebih lanjut. Berdasarkan hasil perhitungan distribusi di Tahun 2013 kontribusi sektor pertambangan dan penggalian terhadap PDRB Kabupaten Anambas merupakan sektor paling dominan yaitu sebesar 35,90\%, sedangkan sumbangan sektor perdagangan, hotel, dan restoran (yang menggambarkan aktifitas kepariwisataan) berada diurutan ke-5 yaitu $0,90 \%$. Demikian pula bila dibandingkan dengan ke-7 kabupaten yang terdapat di dalam Provinsi Riau Kepulauan, kontribusi sektor perdagangan, hotel dan restaurant kepulauan Anambas tahun 2013 berada diurutan terakhir ${ }^{(14)}$.

Kecilnya sumbangan dari sektor perdagangan, hotel dan restaurant ini menunjukkan kurangnya aktifitas kepariwisataan di wilayah ini, padahal potensinya sangat besar terutama obyek wisata bahari. Oleh karenanya kedepan daerah ini perlu mendorong perkembangan kegiatan industri kepariwisataannya terutama 
yang berbasis kelautan sehingga dapat terciptanya pusat-pusat pertumbuhan ekonomi disekitar objek wisata yang dikembangkan, hal ini tentunya sejalan dengan salah satu fokus pembangunannya yaitu pengembangan dibidang pariwisata.

\section{Potensi Wisata}

Kepulauan Anambas kaya dengan keindahan alamnya yaitu berupa terumbu

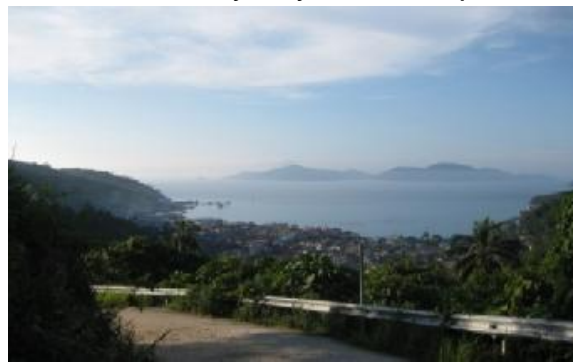

karang yang unik, ekosistem mangrove dan kekayaan seni budayanya. Tarempa misalnya selain sebagai ibukota kabupaten, juga memiliki pantai dengan air laut yang jernih (Gambar 1). Potensi alam ini tentunya bisa dijadikan berbagai objek wisata seperti wisata bahari, wisata budaya, dan wisata agro $\left(\right.$ Tabel-1) ${ }^{(15)}$.

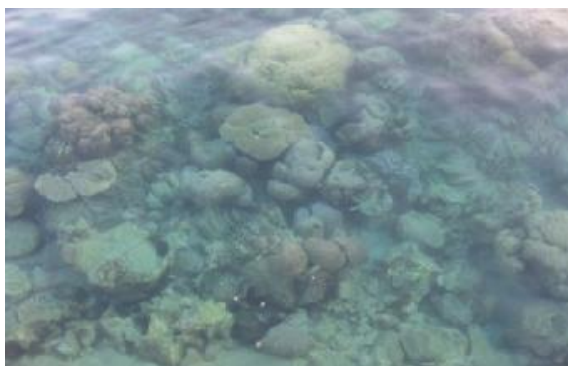

Sumber : Hasil Penelitian, 2012

Gambar 1. Pantai di Kawasan Tarempa

Tabel-1

Kawasan Objek Wisata Menurut Kecamatan di KKA

\begin{tabular}{|c|c|c|}
\hline Kecamatan & Objek Wisata & Jenis Wisata \\
\hline Siantan & Air Terjun Air Bunyi & Wisata Alam \\
\hline Siantan & $\begin{array}{l}\text { Pulau Temawan, Air Nangak Story (Keramat } \\
\text { Siantan) }\end{array}$ & $\begin{array}{l}\text { Wisata Alam, } \\
\text { Wisata Bersejarah }\end{array}$ \\
\hline Siantan Timur & Air Terjun Temburun, Pulau Temuruk & $\begin{array}{l}\text { Wisata Alam } \\
\text { Wisata Bahari }\end{array}$ \\
\hline Palmatak & $\begin{array}{l}\text { Pulau ( Kelong, Batu Alam, Durai, Pahat, Semut, } \\
\text { Penjalin, Lango, Renge, Phanorama dan pulau } \\
\text { Putik ) }\end{array}$ & Wisata Bahari \\
\hline Jemaja & $\begin{array}{l}\text { Pulau Ayam, Pantai Padang Melang, Panorama } \\
\text { Bawah Laut (Terumbu Karang), Pulau (Bawah, } \\
\text { Kuku, dan Pulau Keramut) }\end{array}$ & $\begin{array}{l}\text { Wisata Bahari } \\
\text { Wisata Alam }\end{array}$ \\
\hline Jemaja Timur & $\begin{array}{l}\text { Air Terjun Ulu Maras, Pantai Kusik, Air Raya } \\
\text { Story }\end{array}$ & $\begin{array}{c}\text { Wisata Alam } \\
\text { Wisata Bersejarah }\end{array}$ \\
\hline
\end{tabular}

Sumber : RTRW Kabupaten Kepulauan Anambas Tahun 2009

\section{Akses ke Tujuan Wisata}

Terdapat beberapa cara untuk bisa mencapai Anambas jika berangkat dari Jakarta, terlebih dahulu mengambil penerbangan ke Batam, dari Batam ambil flight Sky Aviation tujuan bandara Matak (Anambas). Dari Matak perjalanan dilanjutkan dengan minibus menuju dermaga, kemudian naik ferry \pm 30 menit ke Tarempa. Alternatif lain bisa ambil flight Jakarta-Tanjung Pinang, dari Tanjung Pinang perjalanan dilanjutkan naik ferry menuju Tarempa, lama perjalanan \pm 8 jam. Pilihan lainnya dari Tanjung Pinang (lewat pelabuhan Kijang) dengan kapal Pelni berkapasitas 900 penumpang tujuan pelabuhan Tarempa, lama perjalanan \pm 17 jam.
Mengenai objek wisata, jika yang diinginkan berwisata serba langkap dan ramai seperti di Bali atau Phuket, Anambas bukanlah tempat yang pas, akan tetapi jika menginginkan pantai-pantai putih bersih, atau keheningan yang menyejukkan serta kicau burung dan gemericik air terjun dengan bebatuan yang menantang, maka Anambas lah tempatnya. Di daerah ini ada beberapa tempat menarik yang perlu dikunjungi diantaranya adalah : pulau Durai (Gambar 2) pulau yang hanya dihuni satu keluarga, menawarkan keindahan alam yang menawan, pulau ini ditetapkan sebagai kawasan konservasi penyu.

Selain itu terdapat pulau Penjalin dan pulau Temawan dengan pasir pantainya bersih 
putih, objek-objek wisata tersebut bisa dicapai menggunakan kapal. Tidak jauh dari pusat kota (Tarempa) terdapat air terjun Temburun yang bertingkat tujuh yang menghadap kelaut (Gambar 3), suasana hutan yang masih perawan terdapat disekitarnya yang

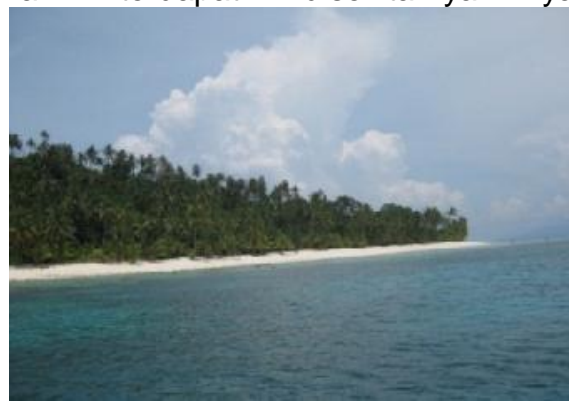

Gambar 2.

Temurun

Sumber : Hasil Penelitian, 2012

Tempat lain yang tak tidak kalah menarik adalah pulau Bawah, menawarkan alam bawah laut yang memikat, bisa untuk diving dan snorkeling, hanya bisa dikunjungi menggunakan kapal. Jika menginginkan hamparan pantai panjang sepanjang mata memandang, bisa mengunjungi pantai Padang Malang, di pulau Jemaja. Juga terdapat pantai Kusik yang indah di Desa Rewak (Gambar 4), dipantai ini bisa untuk berenang, snorkeling, menikmati panorama sekitar dan bersampan.

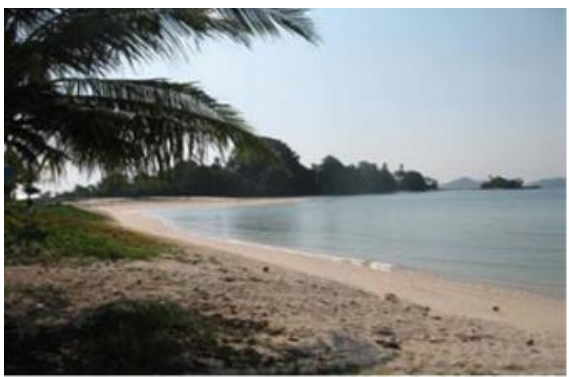

Gambar 4

Pantai Kusik

Sumber : Hasil Penelitian, 2012

Umumnya ditempat objek-objek wisata seperti diatas sangat minim fasilitas baik untuk peristirahatan, permaianan, pusat perbelanjaan maupun pemandu wisata, padahal ketersediaannya mutlak ada karena menyangkut kebutuhan para wisatawan.

\section{d. Fasilitas Pelayanan Kepariwisataan} Tempat Penginapan dan Restoran Sementara ini jumlah penginapan di daerah ini relatif sedikit dimana dalam tahun 2013 ini terdatat 10 hotel melati, dari jumlah tersebut 7 diantaranya terdapat di Tarempa menambah keindahan alam Anambas, objek wisata ini dapat dicapai dengan motor melewati darat (jalan tanah) yang berbukitbukit, dan bisa juga melalui laut pakai kapal dengan sarat air (draft) yang rendah.

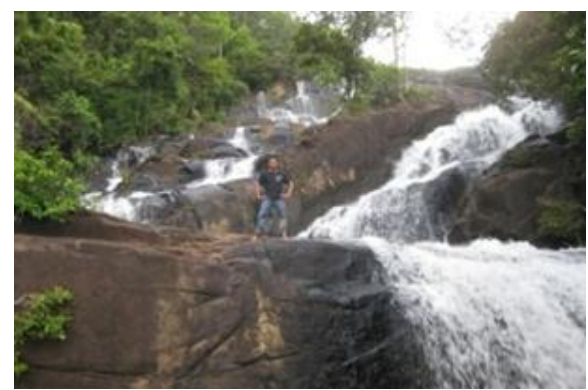

Gambar 3.

Air Terjun Pulau Durai

Dapat diakses melalui darat dengan sepeda motor dari Letung dengan jalan yang berbukit-bukit, dan juga dengan speed boat dari ibu kota Jemaja, kondisi dermaga sangat sederhana. Didalam kota Tarempa terdapat objek wisata yang perlu dikunjungi yaitu Masjid Jami'Baiturrahim dan Vihara Gunung Dewa Siantan (Gambar 5), bangunan bersejarah yang menyejukkan dengan panorama laut yang indah.

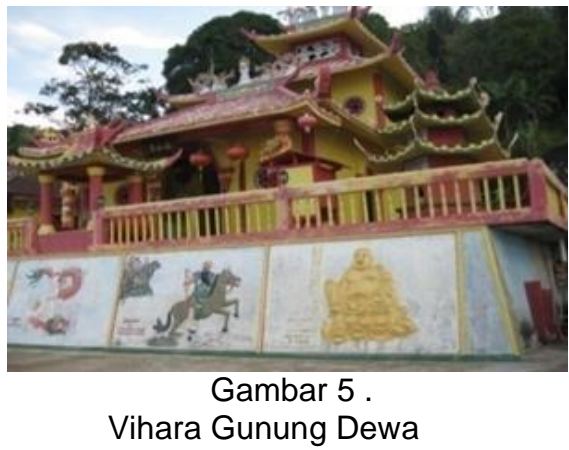

ibukota kecamatan Siantan, selebihnya tersebar di kecamatan Jemaja, jumlah ini menurun dibanding dengan tahun tahun 2012 yang berjumlah 23 buah (Tabel 2) ${ }^{(16)}$. Demikian pula restoran jumlahnya juga mengalami penurunan, padahal kedua fasilitas pelayanan ini memberikan kontribusi yang sangat besar dalam industri pariwisata. Guna mendukung pengembangan industri kepariwisataan, tentunya ketersediaan berbagai fasilitas pelayanan ini perlu ada penambahan karena jumlahnya dirasakan kurang. Apalagi pada saat terdapat event- 
event di daerah ini seperti kegiatan pertemuan antar kecamatan atau antar kabupaten dalam provinsi, cukup sulit menemukan tempat penginapan karena penuh.

Tabel 2.

Jumlah Hotel \& Restoran di Kab Kep Anambas

\begin{tabular}{clcc}
\hline No. & \multicolumn{1}{c}{ Kecamatan } & Hotel Melati & Restoran \\
\hline 1 & Jemaja & 3 & 7 \\
2 & Jemaja Timur & - & - \\
3 & Siantan Selatan & - & - \\
4 & Siantan & - & 15 \\
5 & Siantan Timur & - & - \\
6 & Siantan Tengah & 2 & - \\
7 & Palmatak & 10 & - \\
& J u m I a h & & 23 \\
\hline
\end{tabular}

Sumber: Anambas Dalam Angka, 2014

\section{Fasilitas Belanja}

Pusat-pusat perbelanjaan masih minim dan belum merata di daerah ini, sementara ini baru terpusat di Tarempa, padahal pusat perbelanjaan tersebut penting bagi para wisatawan untuk membeli berbagai keperluan terutama barang-barang yang mempunyai ciri khas atau icon dari daerah sehingga bisa dijadikan sebagai oleh-oleh. Oleh sebab itu dalam usaha meningkatkan aktifitas kepariwisataan di Anambas ini tentunya pusatpusat perbelanjaan ini perlu dikembangkan di setiap daerah.

Perbankan
Dalam Tahun 2013 jumlah bank umum yang beroperasi di Anambas terdiri dari dua bank umum pemerintah, dua bank umum swasta dan satu bank pembangunan daerah.

\section{Kesenian}

Seperti di Pulau Bali dengan tari kecaknya, di kepulaun Anambas juga banyak terdapat berbagai macam kesenian yang dapat dimanfaatkan untuk menunjang pengembangan industri pariwisata seperti taritarian, musik, hadruk dan lain sebagainya (Tabel 3), berbagai kesenian ini perlu dikembangkan dengan menyelenggarakannya pada event-event tertentu.

Tabel 3 :

Kelompok Kesenian Menurut Kecamatan Tahun 2013

\begin{tabular}{cccccc}
\hline \multirow{2}{*}{ Kecamatan } & \multicolumn{5}{c}{ Jenis Kelompokm Kesenian } \\
Jemaja & Tari & Musik & Hadruk & Kembang & Zepin \\
\cline { 2 - 5 } & 1 & 1 & 2 & 3 & 1 \\
\hline Jemaja Timur & 1 & 1 & 1 & 1 & 1 \\
Siantan Selatan & 3 & -- & 1 & 1 & 1 \\
Siantan & 2 & 3 & 6 & 8 & 1 \\
Siantan Timur & 1 & - & 1 & 2 & 1 \\
Siantar Tengah & 1 & 1 & 1 & 1 & 1 \\
Palamatak & 1 & 1 & 3 & 4 & 2 \\
\hline
\end{tabular}

Sumber : Anambas Dalam Angka Th 2014

\section{Kondisi Sarana Transportasi Lokal}

Sebagaimana dijelaskan diatas, sementara ini jenis sarana transportasi yang dapat digunakan menuju kabupaten Anambas yaitu lewat laut dan udara meskipun jadwalnya terbatas. Demikian pula halnya sarana transportasi local baik melalui darat maupun laut, juga masih terbatas. 
Sementara ini jenis sarana yang banyak digunakan baik bagi pekerja, anak sekolah dan keperluan lainnya, untuk angkutan darat didominasi oleh sepeda motor (Gambar 6), dan untuk transportasi laut menggunakan perahu/kapal yang dikenal juga dengan nama

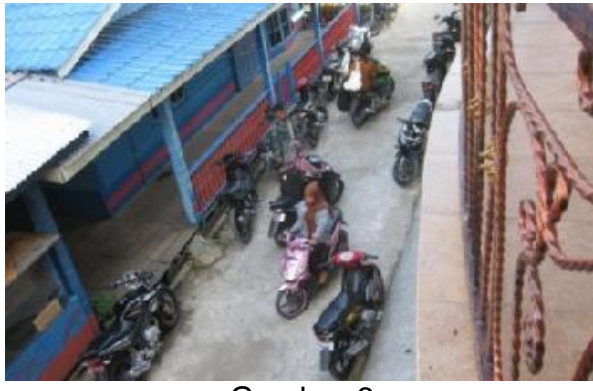

Gambar 6. Angkutan Darat 'pompong' dan speed (Gambar 7) dengan sebarannya seperti terdapat dalam Tabel 4.

Sumber : Hasil Penelitian, 2012

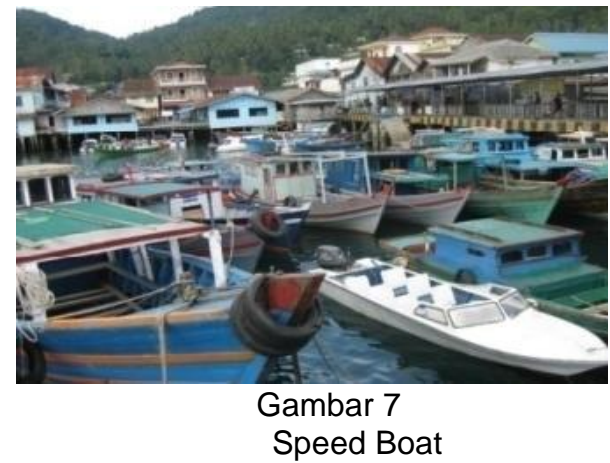

Tabel 4 :

Jumlah Sarana Transportasi Menurut Kecamatan

\begin{tabular}{ccccc}
\hline No & Kecamatan & Mobil & $\begin{array}{c}\text { Jenis Kendaraan } \\
\text { Sepeda Motor }\end{array}$ & Perahu \\
\hline 1 & Jemaja & 12 & 1295 & 587 \\
2 & Jemaja Timur & 7 & 595 & 95 \\
3 & Siantan Selatan & - & 171 & 394 \\
4 & Siantan & 11 & 7410 & 374 \\
5 & Siantan Timur & - & 200 & 536 \\
6 & Siantar Tengah & - & 256 & 296 \\
7 & Palamatak & 14 & 1836 & 896 \\
\hline
\end{tabular}

Sumber : Anambas Dalam Angka, 2014

Armada 'pompong' ini terbuat dari kayu secara tradisional oleh para pengrajin setempat, konstruksi kapal ini cukup kuat dan stabil dalam operasionalnya, meskipun demikian armada pompong ini tidak layak digunakan sebagai kapal angangkutan penumpang karena berbagai kekurangannya seperti, ruang penumpang yang dimuati $\geq 30$ orang tidak dilengkapi dengan tempat duduk, minim peralatan keselamatan, tidak bisa berlayar dengan kondisi perairan bergelombang yang besar.

Sedangkan speed yang terbuat dari material fiberglass dengan kapasitas penumpang 12 orang, biasanya yang sering di carter untuk berbagai keperluan, jadi sejauh ini memang belum ada kapal yang khusus digunakan untuk mengangkut wisatan dengan biaya yang terjangkau. Oleh sebab itu sebagai daerah kepulauan, tidaklah berlebihan bila pengembangan sarana transportasi di Anambas lebih ditekankan pada pengembangan sarana angkutan laut, karena jenis sarana ini yang paling efektif dan efisien dioperasikan.

\section{Kondisi Prasarana Transportasi}

Secara umum terlihat kondisi prasarana transportasi menuju lokasi objek wisata di daerah ini cukup memprihatinkan baik melalui transportasi darat maupun laut, demikian pula dilokasi objek wisata tersebut, beberapa diantaranya dapat digambarkan sebagai berikut:

\section{Air Terjun Temurun}

Akses menuju lokasi ini bila melalui darat baru berupa jalan tanah/setapak yang hanya bisa dilalui dengan sepeda motor (Gambar 8), kalau musim hujan sulit dilalui karena licin. Bila melalui laut, kapal harus turun jangkar ditengah laut dan dilanjutkan dengan rakit/perahu yang mempunyai draft yang pendek, hal ini disebabkan wilayah perairan pantai daerah ini umumnya dangkal. Sama halnya bila berkunjung ke pulau Durai di Kecamatan Siantan Timur, kapal harus turun jangkar ditengah laut dan dilanjutkan dengan rakit/perahu.

\section{Pantai Kusik}

Akses daratnya juga berupa jalan setapak yang berbatu-batu, hanya bisa dilalui dengan 
sepeda motor disepanjang tebing yang curam-curam. Bila melalui laut kapal juga harus turun jangkar di tengfah laut, dan sementara ini untuk menuju pantai, tersedia

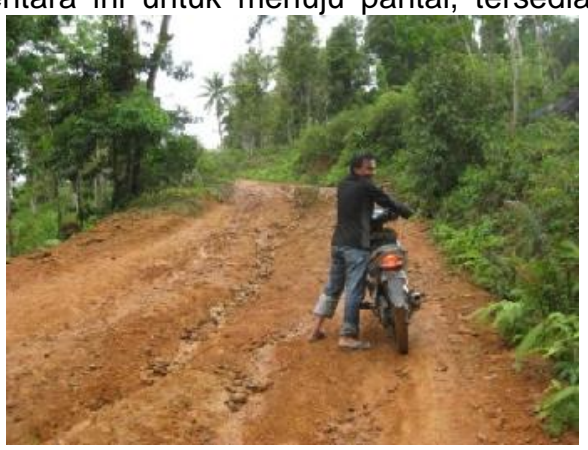

Gambar 8.

Jalan setapak

Sumber : Hasil Penelitian, 2012

\section{Arus Penumpang}

Dalam tahun 2013 kunjungan kapal yang tercatat di pelabuhan Tarempa cukup fluktuatif, karena sangat dipengaruhi oleh kondisi cuaca yang mudah berubah, untuk kapal dalam negeri tercatat sebanyak 947 kunjungan, sedangkan kapal luar negeri sebanyak 119 kunjungan. Kunjungan terbanyak terjadi pada bulan September 2013 karena pada saat tersebut kondisi cuaca lebih baik untuk bepergian, dan yang terkecil pada bulan januari 2013.

Sedangkan jumlah penumpang yang naik sepanjang tahun 2013 di pelabuhan Terempa tercatat sebanyak 26.709 orang, dan penumpang turun sebanyak 39.551 orang. Selanjutnya perkembangan arus penumpang di bandar udara adalah sebagai berikut : banyak penumpang datang di Bandar Udara Matak Tahun 2013 sebanyak 12.113 orang, dan penumpang berangkat sebanyak 12.198 orang, dan sejauh ini belum didapat data khusus mengenai perkembangan arus wisatawan ke Anambas.

\section{Peningkatan Aktifitas Kepariwisataan}

\section{Sarana Transportasi}

Untuk menunjang pengembangan aktifitas kepariwisataan di daerah ini, salah satunya dengan penambahan dan pengembangan sarana dan prasana transportasi, baik untuk akses ke objek wisata maupun di lokasinya. Untuk sarana transportasi laut perlu ada penambahan kapal wisata yang bisa juga difungsikan sebagai kapal angkutan penumpang antar kecamatan di kepulauan Anambas.

\section{Design requirement}

Untuk menentukan jenis dan kapasitas kapal yang cocok dioperasikan, terlebih dahulu tentu perlu diketahui berbagai persyaratan (design requirement) yang meliputi kondisi jetty sederhana terbuat dari kayu yang dilengkapi dengan tangga darurat untuk tempat turun/naik penumpang (Gambar 9).

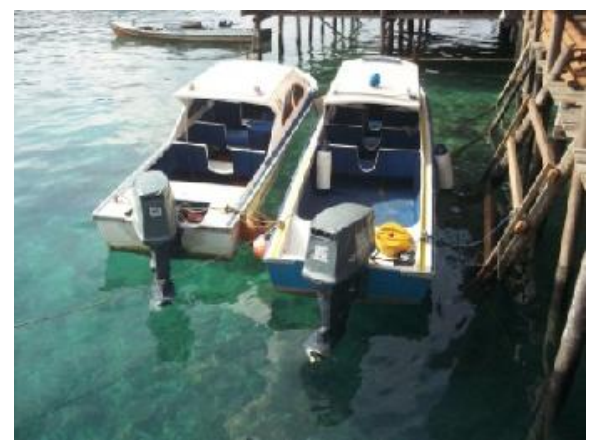

Gambar 9.

Jetty dari Kayu

geografi dan kedalaman wilayah perairan setempat sebagaimana telah dijelaskan diatas. Selain itu beberapa persyaratan lainnya yang perlu ditentukan adalah sebagai berikut :

1. Jarak pelayaran, hal menyangkut penentuan kapasitas tanki untuk persediaan bahan bakar. Dalam hal ini radius pelayaran didasarkan pada jarak lokasi terjauh dari objek wisata ke ibukota kabupaten (Tarempa), dimana yang terjauh adalah objek wisata pantai Padang Melang yang terdapat di kecamatan Jemaja yaitu 38,70 mil, oleh sebeb itu radius pelayaran kapal diambil \pm 100 mil.

2. Badan kapal, diketahui umumnya armada pompong yang beroperasi di perairan Anamabas berbadan tunggal (monohull), mengingat kondisi perairan di daerah ini gelombang cukup besar, maka untuk meningkatkan stabilitas kapal sebaiknya badan kapal berbentuk twin hull (Catamaran).

3. Kecepatan kapal, untuk menghindari gelombang yang cukup besar di perairan, kapal seharusnya di desain dengan kecepatan relative tinggi yaitu $>20$ knot.

4. Draft kapal, agar kapal mudah sandar di berbagai dermaga, tinggi sarat air kapal dibuat < 1,5 meter agar kapal tidak kandas bila merapat ke dermaga.

5. Material kapal, sesuai dengan peraturan International Maritime Organization yang melarang kapal-kapal berbahan fiberglass berlayar dilaut bebas/terbuka dan bergelombang, maka material kapal seharusnya terbuat dari aluminium.

\section{Preliminary Design}

Hasil evaluasi design requirement seperti diuraikan diatas yang dikaitkan dengan hasil penelitian yang pernah dilakukan didaerah ini, 
digunakan sebagai dasar dalam penentuan ukuran utama kapal. Kemudian dengan menggunakan metode parametric ratio design approach dengan bantuan alat statistic p-chart melalui software exel, diperoleh sejumlah ukuran utama kapal penumpang jenis
Catamaran dari berbagai variasi panjang kapal (Tabel 5). Sedangkan jumlah penumpangnya disesuaikan dengan jumlah penumpang rata-rata armada pompong yang banyak beroperasi di perairan Anambas yaitu \pm 36 orang.

Table 5. Variasi Ukuran Utama Kapal Catamaran Angkutan Penumpang

\begin{tabular}{cccccccc}
\hline $\begin{array}{c}\text { Length } \\
(\mathrm{L})\end{array}$ & $\begin{array}{c}\text { Breadth } \\
(\mathrm{B})\end{array}$ & $\begin{array}{c}\text { Hight } \\
(\mathrm{D})\end{array}$ & $\begin{array}{c}\text { Draft } \\
(\mathrm{T})\end{array}$ & $\begin{array}{c}\text { Speed } \\
(\mathrm{V})\end{array}$ & Displ & Sit & HP \\
\hline 10 & 3,46 & 1,13 & 0,53 & 19,7 & 21,6 & 64 & 104 \\
12 & 4,15 & 1,36 & 0,64 & 21,6 & 25,9 & 77 & 196 \\
14 & 4,48 & 1,58 & 0,74 & 23,3 & 30,2 & 90 & 337 \\
16 & 5,53 & 1,81 & 0,85 & 24,9 & 34,5 & 103 & 537 \\
\hline
\end{tabular}

Sumber : Hasil Analisis (Tahun 2012)

Sedangkan untuk kapal yang direncanakan, ukuran utama ( principle dimention) diambil sebagai berikut.

$\begin{array}{lll}\text { Panjang (Lbp) } & =12.00 & \mathrm{M} \\ \text { Lebar muolded (B) } & =4.15 & \mathrm{M} \\ \text { Tinggi (D) } & =1.36 & \mathrm{M} \\ \text { Draft (T) } & =0.64 & \mathrm{M} \\ \text { Kecepatan max (V) } & =21.6 & \text { Knots } \\ \text { Displacement ( ) } & =25.90 & \text { Ton } \\ \text { Kapasitas penumpang } & =36 & \text { orang } \\ \text { Mesin utama } & =2 \times 100 & \text { HP }\end{array}$

Berdasarkan ukuran utama diatas, dapat dibuat desain awal (preliminary design) kapal yaitu berupa Gambar "Rencana Umum Kapal Cepat Catamaran" seperti terlihat pada Gambar 10, dalam hal ini software yang digunakan adalah Auto Cad. Ruangan kapal terdiri dari dua geladak (deck) yaitu deck utama, di dalam deck ini ditempatkan sebanyak 30 kursi (recleining sit) penumpang yang dilengkapi dengan toilet, bagasi barang, coffe shop, dan TV. Sedangkan dibagian atasnya terdapat bridge deck, di deck ini ditempatkan ruang kemudi, peralatan keselamatan yaitu berupa invlatible life raft,pelampung dan life jacket, dibawah geladak utama terdapat ruangan mesin yang dihubungan dengan tangga. Untuk menghirup udara segar para wisatawan bisa berjalan disekeliling deck utama bagian luar yang dilengkapi dengan pagar.
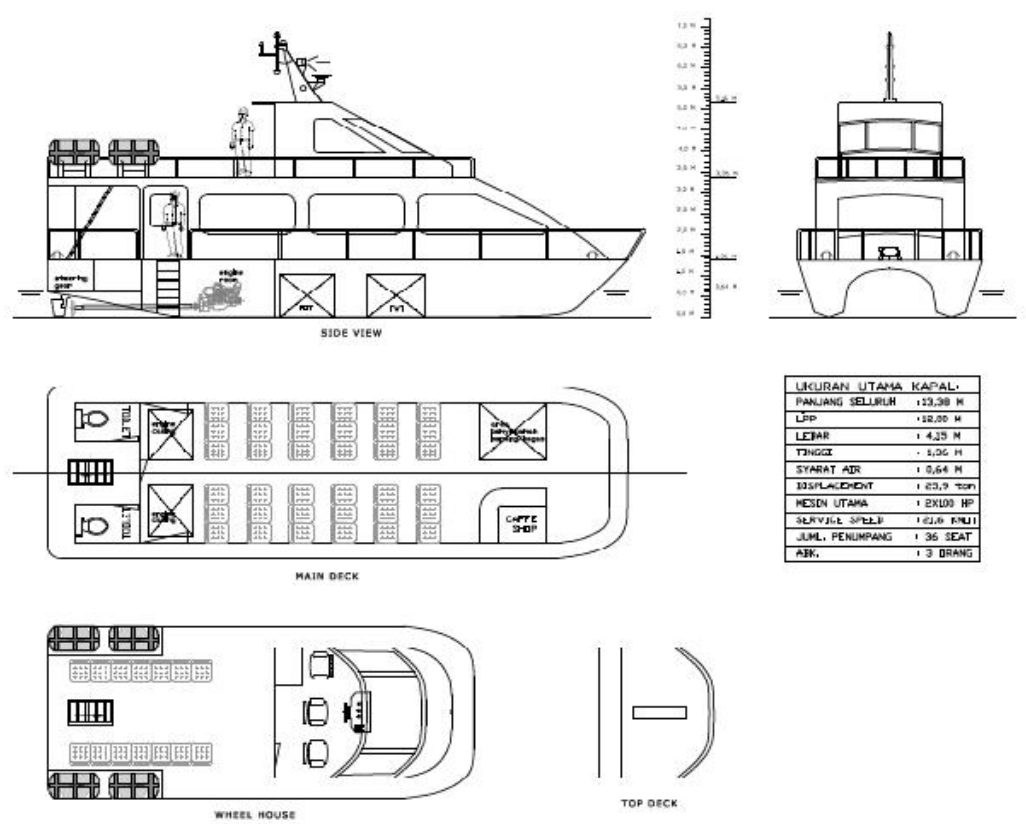

Gambar 10.

Sumber : Hasil Analsis, 2015

Rencana Umum Kapal Cepat Catamaran 


\section{Prasarana Transportasi}

Sebagaimana uraian diatas, kondisi prasarana transportasi di Anambas masih minim dan sederhana, baik akses menuju lokasi objek wisata maupun di lokasi objek wisata itu sendiri. Karenanya dalam pengembangannya, tentunya perlu dibenahi dan dilengkapi dengan peralatan yang memadai, baik prasarana penunjang lainnya, maupun akses jalan menuju ke pantai, dan diharapkan peningkatan tersebut dapat memberikan kemudahan kepada

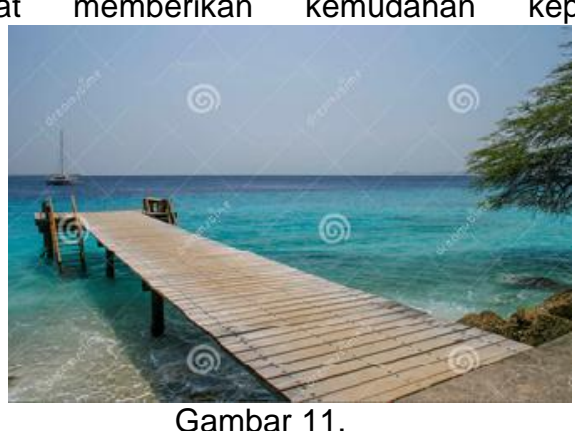

Gambar 11.

Wooden Jetty wisatawan dalam mencapai objek wisata. Khusus di lokasi objek wisata yang mempunyai wilayah pantai yang dangkal, untuk mempermudah akses para pengunjung ke pantai serta untuk keperluan penambatan kapal, perlu dibuat jetty mulai dari pinggir pantai yang menjorok ketengah laut, sebagaimana terlihat pada gambar ilustrasi berikut (Gambar $11)^{(17)}$

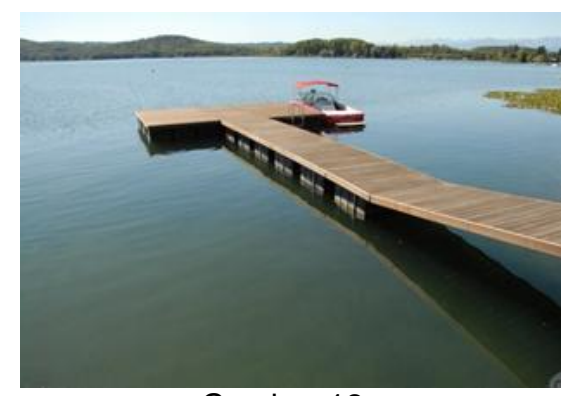

Gambar 12

Floating Jetty

Sumber : https://id.search.yahoo.com/yhs/search?hspart=design jetty

\section{Keterpaduan Moda Transportasi}

Sementara ini moda transportasi yang bisa digunakan ke Anambas adalah moda transportasi udara dan moda transportasi laut, sedangkan untuk transportasi lokal yang bisa digunakan hanya berupa moda transportasi laut saja, meskipun moda transportasi darat (jalan) juga tersedia tetapi hanya berupa sepeda motor. Dalam usaha pengembangan industri pariwisata di daerah ini, adanya keterpaduan antar moda ini sangat diperlukan, meskipun pilihan modanya terbatas. Beberapa simpul transportasi yang perlu segera dikembangkan adalah di pelabuhan Matak Kecamatan Palmatak dan di pelabuhan Tarempa- Kecamatan Siantan Timur. Pada trayek ini terdapat cukup banyak simpul-simpul atau titik persinggungan baik dengan sarana transportasi local maupun dengan moda transportasi lainnya.

\section{Fasilitas Pelayanan Lainnya}

Disamping terciptanya keterpaduan antar moda pada simpul-simpul transportasi, unsur lainnya yang tidak kalah penting yaitu perlu tersedianya berbagai fasilitas kepariwisataan yang meliputi :

\section{Pusat Informasi Kepariwisataan}

Untuk menunjang pengenalan objek-objek tersebut ke masyarakat baik domestic maupun internasional, tentunya perlu dibuat pusatpusat informasi kepariwisataan (tourist information center) baik di daerah Anambas sendiri maupun di luar daerah, untuk daerah Anambas sendiri minimal harus ada di Tarempa sebagai ibu kota kabupatan dan
Letung sebagai ibukota kecamatan Jemaja, informasi yang perlu ada tersebut diantaranya berupa :

1. tempat, yaitu dimana konsumen bisa dengan mudah untuk membeli produk, dalam hal ini tentunya pada agen-agen atau biro-biro perjalanan.

2. harga, tentunya harus dapat mempertemukan antara kemampuan konsumen (secara keuangan) dengan keinginannya untuk berlibur.

\section{Pemasaran}

Dalam industri kepariwisataan aktifitas pemasaran (marketing) perlu dilakukan secara terus menerus, diantaranya berupa :

1. penelitian objek-objek wisata yang akan dipasarkan

2. penelitian konsumen, hal ini berkaitan dengan keinginannya

3. evaluasi data hasil penelitian, apakah sudah memenuhi target

4. pengembangan obyek wisata lainnya.

5. pengembangan kemampuan (skill) sumber daya manusia.

6. promosi, melalui media cetak, media electronik dan paket-paket liburan.

\section{KESIMPULAN}

Berdasarkan hasil kajian berkenaan dengan pengembangan aktifitas kepariwisataan di Kabupaten Kepulauan Anambas, dapat diambil beberapa kesimpulan yaitu Untuk menunjang pengembangan aktifitas kepariwisataan di daerah ini 
penambahan kapal mutlak diperlukan, salah satu jenis kapal yang cocok dikembangkan adalah kapal cepat jenis Catamaran dari aluminum dengan kapasitas tempat duduk sebanyak 36 penumpang.

Perlu dibangun jetty disetiap lokasi objek wisata bahari, yang berfungsi baik sebagai jemabatan penyeberangan maupun tempat sandar kapal Beberapa simpul transportasi yang perlu segera dikembangkan adalah di pelabuhan Matak - Kecamatan Palmatak dan di pelabuhan Tarempa- Kecamatan Siantan Timur. Dan perlu mengembangkan berbagai fasilitas kepariwisataan yaitu berupa pusatpusat informasi dan meningkatkan pemasaran.

\section{UCAPAN TERIMA KASIH}

Penelitian ini merupakan bagian dari kegiatan "Studi Perancangan Kapal Penumpang Untuk Pelayanan Transportasi Laut Antar Pulau Daerah Kabupaten Kepulauan Anambas" dalam Program PKPP Ristek Tahun 2012. Penulis mengucapkan banyak terima kasih kepada rekan-rekan atas bantuan dan kerjasamanya yang baik, sehingga penelitian ini dapat diselesaikan.

\section{DAFTAR PUSTAKA}

1. Jambak Zam, 2014 Pengelolaan Pariwisata Anambas Belum Maksimal. (http:// kepri. antaranews.com/berita/ 30666/pengelolaan-pariwisata-anambasbelum-maksimal), 30 September 2014.

2. J.,Damanik, H.,F.,Weber, Perencanaan Ekowisata: Dari Teori ke Aplikasi. Penerbit Andi. Yogyakarta, Tahun 2006.

3. Khoiron Roni, Multiplier Effects dalam Industri Pariwisata, http:// jejakwisata.com /tourism-studies/ tourism-in-general/122multiplier-effect-dalam-industripariwisata.html, di upload September 2015.

4. Gretzel, U., Mithsce, N., Hwang, Y. H., Fesenmaier, D. R., 2004, "Tell Me Who You Are and I Will Tell You Where to Go: Use of Travel Personalities in Destination Recommendation Systems" Information Technology and Tourism, Vol. 7.

5. Bursan, R., 2006, "Analisis Pengaruh Dimensi Wisata Terhadap Loyalitas Wisatawan (Studi Kasus Di Propinsi Lampung) Jurnal Bisnis dan Manajemen. Volume 3 No.1, ISSN 1411-9366.

6. Sudiarta, M., 2005, "Dampak Fisik, Ekonomi, Sosial Budaya Terhadap
Pembangunan Pariwisata di Desa Serangan Denpasar Bali”, Jurnal Manajemen Pariwisata Vol.4 No. 2.

7. Sigala, M., and Sakellaridis, 2004, "Web User's Cultural Profiles and E-Service Quality: Internationalization Implications for Tourism Web Sites" Information Technology and Tourism, Vol. 7.

8. Yoeti A., Oka, Industri Pariwisata dan Peluang Kesempatan Kerja. Perca, Tahun 2009.

9. Endar Sugiarto, Kusumayadi, Metodologi Penelitian Dalam Bidang Pariwisata. Gramedia Pustaka Utama Tahun 2000.

10 Soebiyantoro Ugy, 2009, Pengaruh Ketersediaan Sarana Prasarana, Sarana Transportasi Terhadap Kepuasan Wisatawan, Fakultas Ekonomi UPN, Surabaya Program Doktoral IImu Manajemen Universitas Brawijaya Malang. Jurnal Manajemen Pemasaran, Vol. 4, No. 1, April 2009.

11. Alaydrus Hadijah, MTI : Transportasi Umum Di Destinasi Wisata Masih Minim (http://industri.bisnis. com/read/ 20160111/98/508716/mti-transportasi-

umum- di-destinasi-wisata-masih-minim ), 11/01/2016.

12. Undang-Undang Nomor 10 Tahun 2009, Tentang Kepariwisataan

13. Peraturan Pemerintah Republik Indonesia Nomor 50 tahun 2011 tentang Rencana Induk Pembangunan Kepariwisataan Nasional Tahun 2010 - 2025.

14. Hardjono Soegeng, Widiati Atik, Hariyanto, Karana Sjafril, Prasetyo Cahyo Andi, Studi Perancangan Kapal Penumpang Untuk Pelayanan Transportasi Laut Antar Pulau Daerah Kabupaten Kepulauan Anambas Tahun 2012.

15. Rencana Tata Ruang Wilayah Kabupaten Kepulauan Anambas, Tahun 2009.

16. Kepulauan Anambas Dalam Angka 2014, Badan Pusat Statistik Kabupaten Kepulauan Anambas.

17. Wooden Jetty, Floating Jetty (https://id. search.yahoo.com/yhs/search?hspart=de sign jetty, diapload November 2015.

18. Peraturan Daerah Provinsi Kepulauan Riau- Rencana Induk Pembangunan Daerah Tahun 2012 -2022.

19. Braun, P., 2004, "Regional Tourism Networks: The Nexus Between ICT Diffusion And Change In Australia", Information Technology and Tourism, Vol. 6. 